\title{
DESIGN OF TOTAL DISSOLVE SOLID (TDS) MEASURING USING CONDUCTIVITY SENSOR AND TEMPERATURE SENSOR DS18B20
}

\author{
Widodo*, Eko Agus Stiyawan \\ Department of Electrical Engineering \\ University of PGRI Adi Buana Surabaya \\ *Corresponding email address: widodo.adibuana@gmail.com
}

\begin{abstract}
TDS meter is a measure of the conductivity of solutes in liquids, this tool is often used as an important component in determining water quality before use. There are still several components to be examined beside TDS, one of which is temperature. Temperature is an important component to measure the feasibility of water. Temperature measuring devices can be used to find out how much the temperature of the liquid being measured. The TDS meter that is already in the general public can only be used to find out the TDS. So, if people want to measure other components such as temperature, a thermometer is needed to measure it, of course this becomes inefficient and requires a higher cost because if you want to measure other components, the public must buy another measuring instrument. Therefore, on this occasion to make measurement tools become more efficient, the writer will design a measuring instrument that can be used to measure 2 components at once, namely a TDS meter and a thermometer designed in one device. TDS meter uses a conductivity sensor and a thermometer uses a DS18B20 waterproof temperature sensor.
\end{abstract}

Keywords: TDS meter, conductivity, quality of water, thermometer.

\section{INTRODUCTION}

One important factor in determining the feasibility of water for human consumption is the Total Dissolve Solid (TDS) in water. TDS meter is a measuring instrument of the conductivity of dissolved substances in a liquid. this tool is often used as one of the important components in determining the quality of water before it is used [1], [2]. The concentration of ionized TDS in a liquid affects the electrical conductivity of the liquid. The higher the concentration of TDS ionized in water, the greater the electrical conductivity of the solution [3]. TDS concentrations in drinking water exceeding the permissible threshold can be dangerous to health because they can cause interference with the kidneys. According to the World Health Organization (WHO), potable drinking water has a TDS level <300 parts per million (ppm) [4]. Meanwhile, according to the Regulation of the Minister of Health of the Republic of Indonesia number 492 of 2010 states the maximum permissible TDS standard is $500 \mathrm{mg} /$ liter or 500 ppm [5].

In addition to TDS there are still several components to be checked, one of them is temperature. Temperature becomes an important component to measure the feasibility of water. Temperature measuring devices can be used to find out how much the temperature of the liquid being measured. The TDS meter that is already in the general public can only be used to find out the TDS. So, if people want to measure other components such as temperature, a thermometer is needed to measure it, of course this becomes inefficient and requires a higher cost because if you want to measure other components, the public must buy another measuring instrument. Therefore, on this occasion to make measurement tools become more efficient, the writer will design a measuring instrument that can be used to measure 2 components at once, namely TDS meters and thermometers that are designed in one device. TDS meter uses a conductivity sensor and a thermometer uses a DS18B20 waterproof temperature sensor that have good accuracy [6].

\section{RESEARCH METHODS}

The design of the TDS and temperature measuring system includes the design of hardware and software. The design of the hardware includes the design of the input and output circuits which 
BEST

Journal of Applied Electrical \& Science Technology - University of PGRI Adi Buana

p-ISSN 2715-2871

e-ISSN 2714-5247

are then connected to the microcontroller circuit. The input circuit includes a TDS sensor and temperature DS18B20 waterproof, while the output circuit is LCD $16 \times 2$.

A sensor consisting of a TDS sensor and a temperature sensor is used to measure conductivity in water and a DS18B20 temperature sensor to measure temperature in water. The sensors are then connected to the Arduino Uno which is connected to the battery as a power source. Sensor data will then be sent to the LCD which shows the results of the conductivity sensor in PPM units, shows the temperature sensor results in units $\left({ }^{\circ} \mathrm{C}\right)$, and shows the results of whether the water quality is suitable for drinking.

The testing method is done in two separate processes. There are partial testing of tools and testing of tools for the whole system. Where the two processes must be carried out sequentially in order to get the expected results. In partial testing, each component / module used will be tested before being assembled in a single system. This test aims to determine whether each component / module is working normally. In the overall testing of this system, the tool will be assembled intact and connected to the load. Where when connected to a load and used to measure into a liquid, accurate results can be displayed. The resulting value will be used for system analysis.

\section{RESULTS AND DISCUSSION}

\section{A. Results}

In this section, the results of the test data are collected during the partial test of the tool and the system as a whole. The data is presented in tables and figures. Among the test results are:

1. TDS Sensor testing uses a mixture of kitchen salt. This test is carried out to determine the level of accuracy of the TDS sensor after converting the value of the sensor voltage to ppm units through the equation obtained in testing the sensor characteristics. The value generated by the sensor will be compared with the value of the TDS meter. Test materials used are tap water and salt with different amounts of salt.

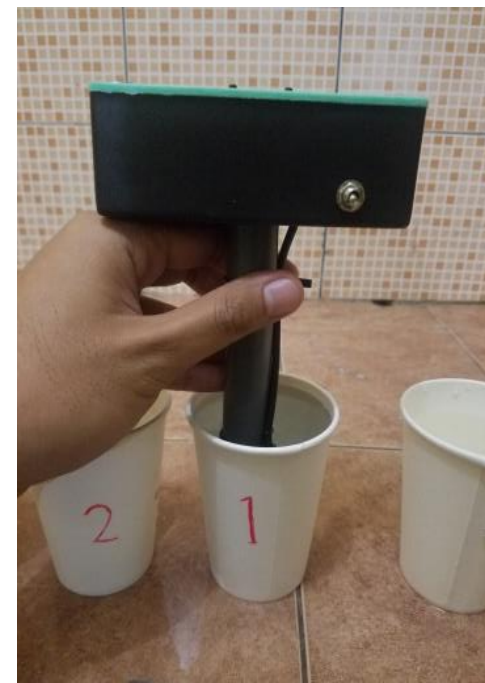

Figure 1. Testing of TDS with 1 teaspoon Salt Mixture

Table 1. TDS Test Results with a mixture of salt

\begin{tabular}{|c|c|c|c|c|}
\hline $\begin{array}{c}\text { Salt } \\
\text { (Measure / } \\
\text { tsp) }\end{array}$ & $\begin{array}{c}\text { TDS } \\
\text { sensor } \\
(\mathrm{ppm})\end{array}$ & $\begin{array}{c}\text { Sensor } \\
\text { Average } \\
\text { (ppm) }\end{array}$ & $\begin{array}{c}\text { TDS } \\
\text { meter } \\
(\mathrm{ppm})\end{array}$ & $\begin{array}{c}\text { Percentage } \\
\text { of Errors } \\
(\%)\end{array}$ \\
\hline \multirow{5}{*}{$\begin{array}{l}\text { Tap water } \\
+0 \\
\text { teaspoon } \\
\text { salt }\end{array}$} & 401.79 & \multirow{5}{*}{398.73} & \multirow{5}{*}{397} & \multirow{5}{*}{0.43} \\
\hline & 399.31 & & & \\
\hline & 398.62 & & & \\
\hline & 398.97 & & & \\
\hline & 396.71 & & & \\
\hline \multirow{5}{*}{$\begin{array}{l}\text { Tap water } \\
+1 \\
\text { teaspoon } \\
\text { salt }\end{array}$} & 504.21 & \multirow{5}{*}{506.93} & \multirow{5}{*}{504} & \multirow{5}{*}{0.44} \\
\hline & 505.58 & & & \\
\hline & 505.98 & & & \\
\hline & 506.60 & & & \\
\hline & 506.90 & & & \\
\hline \multirow{5}{*}{$\begin{array}{l}\text { Tap water } \\
+2 \text { tsp salt }\end{array}$} & 517.19 & \multirow{5}{*}{517.02} & \multirow{5}{*}{518} & \multirow{5}{*}{0.18} \\
\hline & 517.88 & & & \\
\hline & 518.27 & & & \\
\hline & 516.85 & & & \\
\hline & 518.56 & & & \\
\hline \multirow{5}{*}{$\begin{array}{l}\text { Tap water } \\
+5 \text { tsp salt }\end{array}$} & 519.59 & \multirow{5}{*}{520.15} & \multirow{5}{*}{518} & \multirow{5}{*}{0.41} \\
\hline & 520.27 & & & \\
\hline & 519.27 & & & \\
\hline & 520.22 & & & \\
\hline & 520.61 & & & \\
\hline \multirow{5}{*}{$\begin{array}{c}\text { Tap water } \\
+10 \text { tsp } \\
\text { salt }\end{array}$} & 524.37 & \multirow{5}{*}{525.08} & \multirow{5}{*}{528} & \multirow{5}{*}{0.55} \\
\hline & 525.40 & & & \\
\hline & 524.70 & & & \\
\hline & 526.42 & & & \\
\hline & 525.74 & & & \\
\hline
\end{tabular}

2. TDS sensor testing is based on the sensor response time measuring fluid. This test is carried out to determine the response time of the TDS sensor made to test a liquid. For testing various types of liquids have been prepared. To find out how long a stopwatch response is needed to calculate the time. 


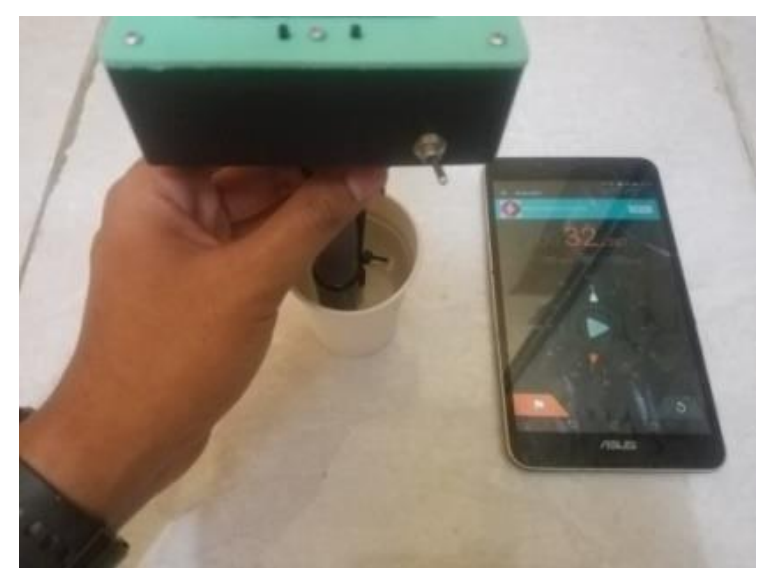

Figure 2. Testing the TDS Sensor Response Using $100 \mathrm{ml}$ of water

Table 2. Sensor Testing Results Based on Sensor Response to Liquids

\begin{tabular}{|c|c|c|c|}
\hline Fluid Type & $\begin{array}{l}\text { TDS sensor } \\
\quad(\mathrm{ppm})\end{array}$ & $\begin{array}{l}\text { Response } \\
\text { Time } \\
\text { (seconds) }\end{array}$ & $\begin{array}{l}\text { Average } \\
\text { Time } \\
\text { (seconds) }\end{array}$ \\
\hline \multirow{5}{*}{$\begin{array}{c}100 \mathrm{ml} \text { tap } \\
\text { water }\end{array}$} & 404.28 & 32 & \multirow{5}{*}{31.8} \\
\hline & 401.49 & 35 & \\
\hline & 402.80 & 31 & \\
\hline & 404.52 & 28 & \\
\hline & 402.10 & 33 & \\
\hline \multirow{5}{*}{$\begin{array}{c}100 \mathrm{ml} \text { tap } \\
\text { water }+5 \\
\text { teaspoons } \\
\text { salt }\end{array}$} & 418.20 & 33 & \multirow{5}{*}{34.8} \\
\hline & 419.66 & 39 & \\
\hline & 418.37 & 36 & \\
\hline & 418.94 & 30 & \\
\hline & 420.31 & 36 & \\
\hline \multirow{5}{*}{$\begin{array}{c}100 \mathrm{ml} \text { tap } \\
\text { water }+10 \\
\text { teaspoons } \\
\text { salt }\end{array}$} & 526.30 & 38 & \multirow{5}{*}{36.8} \\
\hline & 525.17 & 40 & \\
\hline & 526.11 & 34 & \\
\hline & 524.39 & 35 & \\
\hline & 526.60 & 37 & \\
\hline \multirow{5}{*}{$\begin{array}{c}5000 \mathrm{ml} \text { tap } \\
\text { water }\end{array}$} & 415.67 & 39 & \multirow{5}{*}{36.8} \\
\hline & 414.40 & 40 & \\
\hline & 415.29 & 35 & \\
\hline & 415.82 & 33 & \\
\hline & 414.22 & 37 & \\
\hline
\end{tabular}

3. Testing the DS18B20 Temperature Sensor. This test is carried out to determine the accuracy level of the DS18B20 sensor after converting the sensor voltage value to ${ }^{\circ} \mathrm{C}$ units. The value generated by the sensor will be compared with the value of the alcohol thermometer. Test material used is tap water with different temperatures.

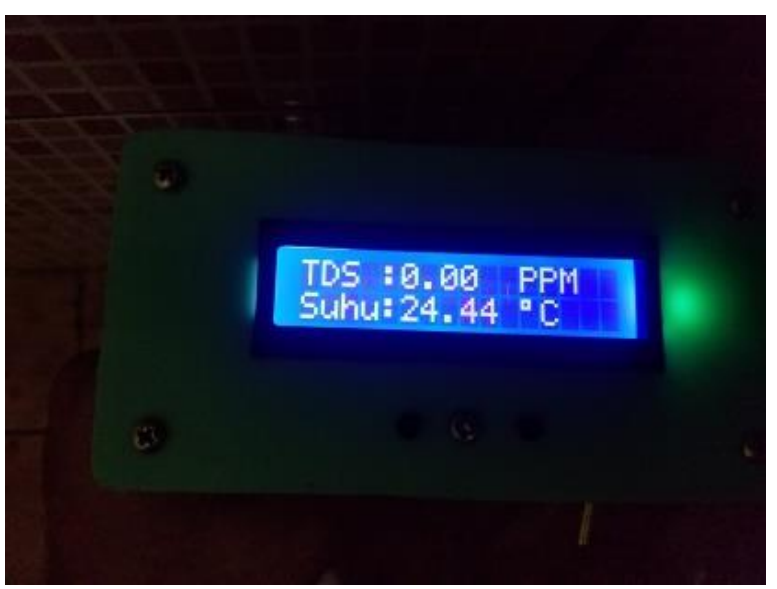

Figure 3. Temperature Sensor Test Results

Table 3. DS18B20 Temperature Sensor Test Results

\begin{tabular}{|c|c|c|c|}
\hline $\begin{array}{c}\text { Thermometer } \\
\left({ }^{0} \mathrm{C}\right)\end{array}$ & $\begin{array}{c}\text { Temperature } \\
\text { Sensor } \\
\text { DS18B20 } \\
\left({ }^{0} \mathrm{C}\right)\end{array}$ & $\begin{array}{c}\text { Average } \\
\text { Temperature } \\
\left({ }^{0} \mathrm{C}\right)\end{array}$ & $\begin{array}{c}\text { Percentage } \\
\text { of Errors } \\
(\%)\end{array}$ \\
\hline \multirow{5}{*}{20} & 17.75 & \multirow{5}{*}{18.11} & \multirow{5}{*}{0.94} \\
\hline & 18.31 & & \\
\hline & 18.06 & & \\
\hline & 18.25 & & \\
\hline & 18.19 & & \\
\hline \multirow{5}{*}{27} & 24.12 & \multirow{5}{*}{24.24} & \multirow{5}{*}{1.11} \\
\hline & 24.81 & & \\
\hline & 24.44 & & \\
\hline & 23.50 & & \\
\hline & 24.37 & & \\
\hline \multirow{5}{*}{33} & 31.48 & \multirow{5}{*}{31.17} & \multirow{5}{*}{1.05} \\
\hline & 30.56 & & \\
\hline & 30.62 & & \\
\hline & 31.08 & & \\
\hline & 32.11 & & \\
\hline \multirow{5}{*}{42} & 41.31 & \multirow{5}{*}{41.86} & \multirow{5}{*}{1,003} \\
\hline & 41.88 & & \\
\hline & 43.13 & & \\
\hline & 42.63 & & \\
\hline & 40.38 & & \\
\hline
\end{tabular}

\section{System Testing}

This test aims to determine whether the system as a whole has worked in accordance with the design. The test was carried out on June 10, 2019 in Sedati Agung Village, Sidoarjo. The choice of these locations is because I live in this location and are indeed residential locations. These locations can already represent the water quality in Sedati Agung Kelurahan in general based on the objectives of this Final Project. The testing process was carried out by taking water samples from 5 
BEST

Journal of Applied Electrical \& Science Technology - University of PGRI Adi Buana

houses in Sedati Agung Village to measure the conductivity.

Table 4. Overall Tool Testing Results

\begin{tabular}{|c|c|c|c|}
\hline Sample & $\begin{array}{c}\text { Temperature } \\
\left({ }^{0} \mathrm{C}\right)\end{array}$ & $\begin{array}{c}\text { TDS } \\
(\mathrm{ppm})\end{array}$ & Results \\
\hline 1 & 29.75 & 415.03 & GOOD \\
\hline 2 & 29.37 & 405.46 & GOOD \\
\hline 3 & 29.87 & 409.22 & GOOD \\
\hline 4 & 29.69 & 402.73 & GOOD \\
\hline 5 & 29.81 & 411.61 & GOOD \\
\hline
\end{tabular}

\section{B. Discussion}

In the testing process the accuracy of the TDS sensor is carried out five times by the sensor and once by the TDS meter for the same liquid. The results of the ten measurements by the sensor are then averaged so that they can be compared with the value of the TDS meter measurement to find out what percentage of the error is generated. The testing process was carried out for five different liquids whose salt dose. From the five measurements obtained an average percentage error of 0.402 .

In the process of testing the response of the TDS sensor five measurements are carried out by sensors on different types of liquids. The results of five measurements by the sensor are then averaged so that it can be seen how the average sensor process responds to the liquid until it appears on a stable LCD. The testing process was carried out for four different liquid types of water. From these measurements an average response time of \pm 30 seconds is obtained.

In the testing process the accuracy of the DS18B20 sensor is carried out 2 experiments and each experiment is carried out five times by the sensor and once by the Alcohol thermometer for the same liquid. The results of the five measurements by the sensor are then averaged so that they can be compared with the results of the alcohol thermometer measurement to find out what percentage of the error is generated. The testing process was carried out for five liquids with different temperatures. From the five measurements obtained an average percentage error of $0.936 \%$.
From the results of testing the tool as a whole as shown in the table it can be concluded that the tool has worked in measuring TDS and sample temperature in Kelurahan Sedati Agung. The results of sample measurements from five locations show TDS ranging from $400 \mathrm{ppm}$ to $416 \mathrm{ppm}$ with an average of $408.81 \mathrm{ppm}$ and temperatures ranging from $290 \mathrm{C}$. Based on the Minister of Health Regulation PERMENKES 492 / Menkes / Per / IV / 2010 concerning the maximum TDS standard is $500 \mathrm{mg} / \mathrm{L}$ or ppm $25 \mathrm{~N}$. It can be concluded that TDS still meets the maximum allowable content.

\section{CONCLUSION}

From the results of testing tools and analysis that has been done, it can be concluded that:

1. The creation of a TDS tool that uses a conductivity sensor and a temperature sensor that works GOOD and can be used for measuring liquid and with varied mineral deposits.

2. The creation of TDS has a fairly large level of accuracy due to the error percentage of the three sensors is quite small namely the TDS sensor at $0.402 \%$, the temperature sensor at $0.936 \%$ and has a measurement response of \pm 30 seconds.

\section{ACKNOWLEDGMENT}

Acknowledgments and awards need to be conveyed to PGRI Adi Buana University Surabaya Faculty of Industrial Technology especially the Electrical Engineering study program, which has provided laboratory facilities for the completion of writing this article. Also, Acknowledgments and appreciation of the authors convey to all parties who have provided assistance in the form of guidance, direction, advice, support and convenience from the beginning to the end of the preparation of the Final Project.

\section{REFERENCE}

[1] Amani, Fauzi dan Kiki Prawiroredjo. 2016. Alat Ukur Kualitas Air Minum dengan Parameter PH, Suhu, Tingkat kekeruhan, dan Jumlah Padatan yang Terlarut. 
[2] Effendi, H. 2003. Telaah Kualitas Air Bagi Pengelolaan Sumber Daya dan Lingkungan Perairan. Cetakan Kelima. Yogyakarta: Kanisius.

[3] Hedlyni. 2011. Pendeteksi Kekeruhan Air Berbasis Mikrokontroler AT89551 dengan Sensor Foto resistor dan LED Inframerah. Fakultas Matematika dan Ilmu Pengetahuan Alam, Universitas Andalas.

[4] WHO, 2003. Total dissolved solids in Drinking-water. World Health Organization, Geneva, Switzerland.

[5] Suripin, 2002. Pelestarian Sumber Daya Tanah dan Air. Yogyakarta: ANDI.

[6] Sujiwa, Akbar, and Sagita Rochman. "Pengembangan Sistem Kontrol Serta Monitoring Suhu dan Volume Air Berbasis Web Pada Perangkat Desalinasi Air Laut." SNHRP (2019): 1-9. 